\title{
Increased attrition of memory T cells during sepsis requires 2B4
}

\author{
Jianfeng Xie, ${ }^{1}$ Ching-wen Chen, ${ }^{1}$ Yini Sun, ${ }^{1}$ Sonia J. Laurie, ${ }^{1}$ Wenxiao Zhang, ${ }^{1}$ Shunsuke Otani, ${ }^{1}$ \\ Gregory S. Martin, ${ }^{2}$ Craig M. Coopersmith, ${ }^{1,3}$ and Mandy L. Ford ${ }^{1,4}$ \\ 'Department of Surgery, and 'Division of Pulmonary, Allergy, Critical Care and Sleep, Department of Medicine, Emory \\ University School of Medicine, Atlanta, Georgia, USA. ${ }^{3}$ Emory Critical Care Center, Department of Surgery, and ${ }^{4}$ Emory \\ Transplant Center, Division of Transplantation, Department of Surgery, Emory University School of Medicine, Atlanta, \\ Georgia, USA.
}

Recent seminal studies have revealed that laboratory mice differ from adult humans with regard to the frequency, number, and distribution of memory T cells. Because our data show that memory T cells are more susceptible to sepsis-induced death than naive T cells, in this study we developed a model in which mice possess a memory $T$ cell compartment more similar to that of adult humans, to better study immune responses during sepsis in the more physiologically relevant context of high frequencies of memory T cells. Using this model, we found that CD44 ${ }^{\text {hi }}$ memory $\mathrm{T}$ cells significantly upregulated the coinhibitory molecule 2B4 during sepsis, and 2B4 memory $T$ cells coexpressed markers of both activation and exhaustion. Genetic deficiency in 2B4 resulted in decreased mortality during sepsis. Mechanistically, this decreased mortality was associated with reduced caspase-3/7+ apoptotic T cells in $2 \mathrm{~B}^{-/-}$relative to $\mathrm{WT}$, septic hosts. These results were corroborated by analysis of PBMCs isolated from human patients with sepsis, which showed increased frequencies of caspase-3/7+ apoptotic cells among $2 \mathrm{~B}^{+}$relative to $2 \mathrm{~B} 4-$ T cells. Thus, 2B4 plays a critical role in sepsis-induced apoptosis in both murine memory T cells and those isolated from human patients with sepsis.

Authorship note: CMC and MLF contributed equally to this work.

Conflict of interest: The authors have declared that no conflict of interest exists.

Copyright: (c) 2019 American Society for Clinical Investigation

Submitted: November 29, 2018 Accepted: February 19, 2019 Published: April 4, 2019.

Reference information: JCl Insight. 2019;4(7):e126030. https://doi. org/10.1172/jci.insight.126030

\section{Introduction}

Sepsis is the leading cause of death among critically ill patients in the US, with between 270,000 and 370,000 people dying from the disease annually (1). Outside of antibiotics, treatment of sepsis is nonspecific, aimed at early cardiopulmonary resuscitation to minimize the adverse systemic effects of infection (2). Although this approach is frequently effective (3), there are no approved therapeutics available for sepsis once antibiotics and supportive therapy fail (4). As the third most common cause of death in the US following heart disease and cancer (5-8), sepsis represents a prevalent and deadly public health issue.

$\mathrm{T}$ cells play a crucial role in host immune response during sepsis $(4,9,10)$. Moreover, it is well known that a significant $T$ cell loss occurs during sepsis both in animal and in human studies (9-14). We recently showed that sepsis results in the preferential attrition of memory phenotype $\mathrm{CD}^{+} \mathrm{T}$ cells relative to naive $\mathrm{CD} 8^{+} \mathrm{T}$ cells via apoptosis (15), suggesting that the frequency of $\mathrm{CD} 8^{+}$memory $\mathrm{T}$ cells in a given individual before the onset of sepsis could be an important factor in sepsis pathogenesis. In normal adult human subjects, the peripheral $\mathrm{T}$ cell compartment consists of about $30 \%-70 \%$ memory $\mathrm{T}$ cells. In contrast, laboratory mice housed under specific pathogen-free conditions possess only about $10 \%-20 \%$ memory $\mathrm{T}$ cells $(16,17)$. A recent seminal study by Beura and colleagues showed that exposure of laboratory animals to pet store or feral mice resulted in the rapid generation of $\mathrm{CD} 8^{+}$memory $\mathrm{T}$ cell populations in these animals, at levels that approximate those observed in adult humans (18). Thus, to better model the antigen-experienced immune system of human patients, in this study we have developed a model to generate mice that possess a memory $\mathrm{T}$ cell compartment more similar to that of adult humans, to study the $\mathrm{T}$ cell response to sepsis in the more physiologically relevant context of high frequencies of $\mathrm{CD}^{+}$memory $\mathrm{T}$ cells.

The ultimate outcome of $\mathrm{T}$ cell activation is determined by the balance of costimulatory and coinhibitory molecule signals received during $\mathrm{T}$ cell priming or recall (19). In addition to naive precursors, memory $\mathrm{T}$ cells are potently regulated by ligation of coinhibitory receptors on their cell surfaces (20-22). 
Furthermore, numerous studies have demonstrated that coinhibitory signals play a critical role in regulating $\mathrm{T}$ cell responses during sepsis (23-28). For example, increased expression of coinhibitory molecules, including programmed cell death 1 (PD-1) and $\mathrm{B}$ and $\mathrm{T}$ lymphocyte attenuator, has been identified on the surface of $\mathrm{T}$ cells isolated from patients with sepsis as opposed to those obtained from controls without sepsis (14), and blockade of these pathways may represent a therapeutic strategy for the amelioration of morbidity and mortality in individuals with sepsis $(24,26,27,29-34)$. In particular, many published studies demonstrate that anti-PD-1 and anti-programmed cell death ligand 1 (anti-PD-L1) improve survival in murine models of sepsis $(25,26,32,35-41)$, and a clinical trial of anti-PD-L1 in sepsis has been conducted (https://clinicaltrials.gov NCT02576457). In addition, we recently found that 2B4 signals are significantly associated with the outcome of sepsis pathogenesis (42). 2B4-knockout mice had a significantly better survival rate after cecal ligation and puncture (CLP) compared with WT mice. However, the role of these coinhibitory molecules on memory $\mathrm{CD}^{+} \mathrm{T}$ cell responses during sepsis is not well understood. In this study, we used a potentially novel "memory mouse" model to interrogate the role of the $2 \mathrm{~B} 4$ coinhibitory pathway in sepsis pathogenesis in antigen-experienced hosts, and this model may better recapitulate the mature immune systems of adult patients with sepsis.

\section{Results}

Generation of "memory mice" for use in studies of sepsis pathogenesis. Naive B6 animals were first infected with a Listeria monocytogenes bacterial infection followed by an lymphocytic choriomeningitis virus (LCMV) viral infection as described in Methods to generate an effector $\mathrm{T}$ cell response that would resolve and generate memory $\mathrm{T}$ cells (Figure 1A). We assessed the magnitude and kinetics of the $\mathrm{CD} 4^{+}$and $\mathrm{CD} 8^{+} \mathrm{T}$ cell responses during the expansion and contraction of the immune response following these infections. The frequency of $\mathrm{CD} 44^{\text {hi }}$ cells among both $\mathrm{CD}^{+}$and $\mathrm{CD} 8^{+} \mathrm{T}$ cell populations significantly increased on day 10 after Listeria infection and then significantly decreased by day 25 after Listeria infection (Figure 1, B-D). Mice were then infected with LCMV, and 10 days later the frequency of CD44 $4^{\text {hi }}$ cells among both $\mathrm{CD}^{+}$and $\mathrm{CD}^{+} \mathrm{T}$ cell populations significantly increased again (day 40, Figure 1, B-D) and then decreased on day 55 after Listeria infection (day 25 after LCMV infection). In sum, results indicate that our model resulted in the generation of animals that possess a significantly increased frequency of CD $44^{\text {hi }}$ memory T cells in both the CD4 ${ }^{+}$and $\mathrm{CD}^{+} \mathrm{T}$ cell compartments (CD4: $38.4 \% \pm 1.3 \%$ versus $20.1 \% \pm 1.5 \%, P<0.0001$; CD8: $54.6 \% \pm 1.5 \%$ versus $18.1 \% \pm 1.4 \%, P<0.0001$ ) (Figure $1, \mathrm{E}$ and $\mathrm{F}$ ). As shown in Supplemental Figure 1 (supplemental material available online with this article; https://doi.org/10.1172/jci.insight.126030DS1), the increase in memory T cells shown in Figure 1, E and F, was due almost entirely to an increase in CD44 ${ }^{\text {hi }}$ CD62 $\mathrm{L}^{\text {lo }}$ effector memory cells $\left(\mathrm{T}_{\mathrm{em}}\right)$ in both the $\mathrm{CD} 4^{+}$and $\mathrm{CD} 8^{+} \mathrm{T}$ cell compartments.

"Memory mice" exhibit significantly increased T cell loss during sepsis compared with naive hosts. Memory mice, as well as age- and housing-matched naive controls, were then subjected to CLP. Animals were sacrificed at 24 hours after CLP to assess the impact of sepsis on the magnitude of the T cell compartment. We found that antigen-experienced memory mice exhibited a statistically significant increase in loss of $\mathrm{CD}^{+}$(but not $\left.\mathrm{CD}^{+}\right) \mathrm{T}$ cells following sepsis compared with naive septic animals $\left(2.68 \times 10^{6} \pm 1.85 \times 10^{5}\right.$ versus $5.28 \times$ $10^{6} \pm 3.01 \times 10^{5}, P<0.0001$ ) (Figure 2, A and B). Based on the results that CLP led to a greater loss of $\mathrm{CD}^{+} \mathrm{T}$ cells in memory mice compared with naive septic control animals, we hypothesized that memory mice would exhibit increased mortality during sepsis. However, analysis of 7-day survival revealed no statistically significant difference between naive and memory mice after CLP (Figure 2C).

Given the findings that memory mice exhibited increased attrition of $\mathrm{CD}^{+} \mathrm{T}$ cell populations relative to naive controls following sepsis, we next sought to determine whether sepsis has a differential effect on naive $\left(C D 44^{\text {lo }}\right)$ versus memory $\left(C D 44^{\text {hi }}\right) \mathrm{T}$ cell populations. Memory mice, generated as described above, were subjected to CLP or sham operation and splenocytes were harvested 24 hours after surgery. Results indicated that compared with the sham operation, both $\mathrm{CD} 44^{\text {hi }} \mathrm{CD} 4^{+}\left(2.81 \times 10^{6}\right.$ $\pm 7.07 \times 10^{5}$ versus $\left.5.17 \times 10^{6} \pm 7.88 \times 10^{5}, P=0.038\right)$ and $\mathrm{CD} 44^{10} \mathrm{CD}^{+}\left(5.56 \times 10^{6} \pm 5.60 \times 10^{5}\right.$ versus $7.00 \times 10^{6} \pm 6.64 \times 10^{5}, P=0.011$ ) T cells were significantly reduced following sepsis (Figure $2, \mathrm{D}$ and $\mathrm{E})$, indicating that sepsis-induced $\mathrm{T}$ cell attrition affects both naive and memory CD4 ${ }^{+} \mathrm{T}$ cells. In contrast, for $\mathrm{CD}^{+} \mathrm{T}$ cells, only the CD $44^{\text {hi }}$ population was significantly reduced following CLP $(2.57 \times$ $10^{6} \pm 6.68 \times 10^{5}$ versus $5.23 \times 10^{6} \pm 6.37 \times 10^{5}, P=0.010$ ) (Figure $2, \mathrm{~F}$ and G), while the CD $44^{10} \mathrm{CD} 8^{+}$ $\mathrm{T}$ cell population was preserved. These data indicate that sepsis-induced $\mathrm{T}$ cell attrition preferentially affects memory $\mathrm{CD} 8^{+} \mathrm{T}$ cell populations compared with naive $\mathrm{CD} 8^{+} \mathrm{T}$ cell populations. 
$2 B 4$ coinhibitory receptor is preferentially upregulated on CD44 memory $T$ cells during sepsis. Because we found that $\mathrm{CD} 44^{\text {hi }} \mathrm{CD} 8^{+} \mathrm{T}$ cells were preferentially lost relative to $\mathrm{CD} 44^{\text {lo }} \mathrm{CD} 8^{+} \mathrm{T}$ cells during sepsis, we queried the mechanism underlying increased $\mathrm{CD} 8^{+}$memory $\mathrm{T}$ cell sensitivity to cell loss during sepsis. Because we previously found that 2B4 expression was significantly upregulated on total CD4 ${ }^{+}$ and $\mathrm{CD} 8^{+} \mathrm{T}$ cell populations following sepsis, we posited that it may play a crucial role in $\mathrm{CD}^{+}$memory $\mathrm{T}$ cell loss in these memory mice. To test this, we first assessed expression of the 2B4 coinhibitory receptor on naive $\mathrm{CD} 44^{\mathrm{lo}}$ and memory $\mathrm{CD} 44^{\mathrm{hi}} \mathrm{CD} 4^{+}$and $\mathrm{CD} 44^{\mathrm{hi}} \mathrm{CD} 8^{+} \mathrm{T}$ cells in memory mice at 24 hours after CLP. The results showed that the frequency of 2B4-expressing $\mathrm{T}$ cells increased in both the $\mathrm{CD} 44^{\text {hi }} \mathrm{CD}^{+}{ }^{+}$(Figure 3, $\mathrm{A}$ and $\mathrm{B}$ ) and $\mathrm{CD} 44^{\text {hi }} \mathrm{CD} 8^{+}$(Figure 3, C and D) subsets following sepsis but not in the $\mathrm{CD} 44^{10} \mathrm{CD} 4^{+}$and $\mathrm{CD} 44^{10} \mathrm{CD} 8^{+}$subsets.

To understand the impact of 2B4 expression on memory $\mathrm{T}$ cells during sepsis, we evaluated differences in $\mathrm{T}$ cell activation between $2 \mathrm{~B} 4^{\mathrm{hi}} \mathrm{CD} 44^{\mathrm{hi}}$ and $2 \mathrm{~B} 4^{\mathrm{lo}} \mathrm{CD} 44^{\mathrm{hi}}$ memory $\mathrm{T}$ cells in both the $\mathrm{CD} 4^{+}$and $\mathrm{CD} 8^{+} \mathrm{T}$ cell compartments. Compared with $2 \mathrm{~B} 4^{-} \mathrm{CD} 4^{+} \mathrm{T}$ cells, CD25 and PD-1 were significantly upregulated on $2 \mathrm{~B} 4{ }^{+} \mathrm{CD} 4{ }^{+} \mathrm{T}$ cells $(\mathrm{CD} 25: 20.13 \% \pm 1.11 \%$ versus $14.33 \% \pm 0.42 \%, P=0.0001 ; \mathrm{PD}-1: 92.44 \% \pm 1.12 \%$ versus $68.16 \% \pm 1.84 \%, P<0.0001)$. There was no difference in expression of CD69 between $2 \mathrm{~B} 4{ }^{+} \mathrm{CD} 4^{+}$ and $2 \mathrm{~B} 44^{-} \mathrm{CD} 4^{+} \mathrm{T}$ cells (Figure 3, E and F). In contrast, expression of CD25, CD69, and PD-1 were all significantly higher on $2 \mathrm{~B} 4^{+} \mathrm{CD} 8^{+} \mathrm{T}$ cells relative to $2 \mathrm{~B} 4^{-} \mathrm{CD} 8^{+} \mathrm{T}$ cells $(\mathrm{CD} 25: 13.94 \% \pm 2.17 \%$ versus $3.72 \%$ $\pm 0.43 \%, P=0.0002$; CD69: $15.37 \% \pm 1.48 \%$ versus $11.53 \% \pm 1.07 \%, P=0.0495 ; \mathrm{PD}-1: 82.60 \% \pm 1.41 \%$ versus $47.33 \% \pm 2.41 \%, P<0.0001$ ) (Figure $3, \mathrm{G}$ and $\mathrm{H}$ ).

$2 \mathrm{~B} 4$ deficiency rescues memory mice from sepsis mortality. Because we found that $2 \mathrm{~B} 4^{+}$memory $\mathrm{T}$ cells exhibited markers of both increased activation (CD25, CD69) and exhaustion (PD-1) compared with 2B4$\mathrm{T}$ cells during sepsis, we queried the functional impact of $2 \mathrm{~B} 4$ signaling during sepsis in memory mice by interrogating overall mortality in WT versus $2 \mathrm{~B} 4^{-/-}$memory mice following CLP. WT and $2 \mathrm{~B} 4^{-/-}$memory mice were generated using the method described above. We observed no difference in the frequency of $\mathrm{CD}^{+}$or $\mathrm{CD}^{+}$memory $\mathrm{T}$ cells generated following Listeria and LCMV infections in $2 \mathrm{~B}^{-/-}$compared with WT animals before sepsis induction (data not shown). Animals were then subjected to CLP. Importantly, results demonstrated a significant improvement in the 7-day survival of $2 \mathrm{~B} 4^{-/-}$memory mice compared with WT memory mice (Figure 4A).

To interrogate the cellular changes associated with improved mortality in the $2 \mathrm{~B} 4^{-/-}$memory mice, we assessed the magnitude of the $\mathrm{CD}^{+}$and $\mathrm{CD} 8^{+} \mathrm{T}$ cell compartments in $2 \mathrm{~B} 4^{-/-}$and $\mathrm{WT}$ memory mice following CLP. Results indicated that the absolute numbers of $\mathrm{CD} 44^{\mathrm{hi}} \mathrm{CD} 4^{+} \mathrm{T}$ cells were significantly higher in $2 \mathrm{~B} 4^{-/-}$memory mice with sepsis compared with WT memory mice with sepsis $\left(5.71 \times 10^{6} \pm 1.04\right.$ $\times 10^{6}$ in $2 \mathrm{~B}^{-/-}$versus $2.81 \times 10^{6} \pm 7.07 \times 10^{5}$ in WT, $P=0.030$ ) (Figure $4, \mathrm{~B}$ and $\mathrm{C}$ ). Absolute numbers of $\mathrm{CD} 44^{\mathrm{hi}} \mathrm{CD}^{+} \mathrm{T}$ cells in $2 \mathrm{~B} 4^{-/-}$memory mice with sepsis compared with WT memory mice with sepsis were not significantly different but showed a trend toward being increased (Figure 4, D and E).

To determine whether a difference in induction of apoptosis might underlie these alterations in cell numbers and mortality in $2 \mathrm{~B} 4^{-/-}$mice during sepsis, the frequency of cells expressing active caspase-3/7 and staining positively with SYTOX, a viability dye, was assessed. Results indicated that while the frequency of caspase- $3 / 7^{+} \mathrm{SYTOX}{ }^{+} \mathrm{CD} 4^{+} \mathrm{T}$ cells was not significantly different between $\mathrm{WT}$ and $2 \mathrm{~B} 4^{-/-}$mice

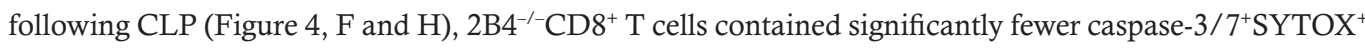
cells compared with WT CD8 ${ }^{+}$T cells following CLP (Figure 4, G and I).

Human $2 B 4^{+} T$ cells exhibit increased frequencies of active caspase- $3 / 7^{+}$cells compared with $2 B 4^{-} T$ cells during sepsis. Given these data suggesting that 2B4 expression can promote mortality and immune dysregulation in antigen-experienced mice following sepsis, we next sought to understand the association of 2B4 expression with $\mathrm{T}$ cell death in human septic patients. To approach this, we collected PBMCs under an IRB-approved protocol from $n=10$ healthy donors (HDs) or $n=14$ patients who were hospitalized in the intensive care unit (ICU) and had received a diagnosis of sepsis within 24 hours. Patient demographic and clinical data are summarized in Supplemental Table 1. Results indicated that total frequencies of $\mathrm{CD}^{+}$and $\mathrm{CD} 8^{+}$naive $\mathrm{T}$ cells, central memory $\mathrm{T}$ cells, $\mathrm{T}_{\mathrm{em}}$, and terminal-differentiated effector memory cells $\left(\mathrm{T}_{\mathrm{emra}}\right)$ were not different between patients with sepsis versus HDs (Figure 5A). Moreover, frequencies of cells expressing active caspase-3/7, an indicator of apoptotic cell death, were not increased in memory $\mathrm{T}$ cell subsets compared with naive $\mathrm{T}$ cells in either the $\mathrm{CD} 4^{+}$or $\mathrm{CD} 8^{+} \mathrm{T}$ cell compartment of patients with sepsis (Figure $5 \mathrm{~B}$ ), indicating that in these patients, memory $\mathrm{T}$ cell status alone was insufficient to confer an increased frequency of apoptotic cells following sepsis. However, analysis of the $2 \mathrm{~B} 4^{+}$subset within the $\mathrm{CD} 8^{+} \mathrm{T}$ cell compartment 
A

Listeria monocytogenes
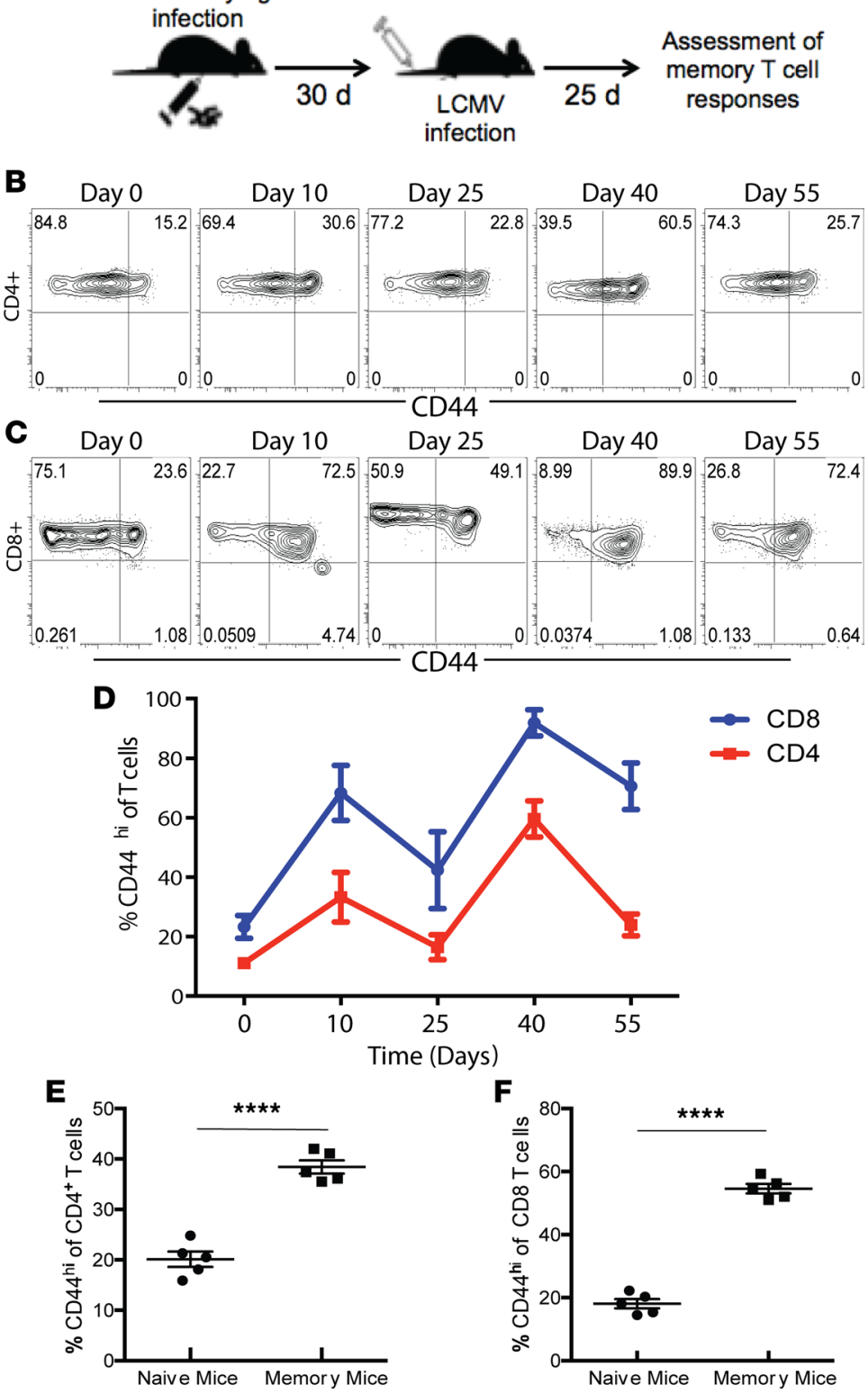

Figure 1. Generation and characterization of polyclonal memory T cells following infection. Naive B6 mice were infected with Listeria and allowed to develop a population of memory T cells. Mice were infected with LCMV 30 days later. Establishment of memory was assessed by flow cytometry 25 days after LCMV infection. (A) Schematic of experimental design. (B and C) Representative flow plots depicting CD44 expression on splenic CD4 ${ }^{+} \mathrm{T}$ cells following infection. (D) Expansion of $C D 44^{+}$T cells in the spleen over time following antigenic challenge $(n=20 /$ group). ( $E$ and $\mathbf{F}$ ) Summary of frequency of CD44 $4^{\text {hi }}$ cells among $\mathrm{CD} 4^{+}$and $\mathrm{CD} 8^{+} \mathrm{T}$ cell compartments in memory mice on day 55 following infection (per schematic in A) in the blood, compared with the frequency of CD44 ${ }^{\text {hi }}$ cells in the blood of naive uninfected animals. Groups $(n=5)$ were compared with the Mann-Whitney nonparametric test. ${ }^{* * *} P<0.0001$. All data expressed as mean \pm SEM.

revealed an increased frequency of caspase- $3 / 7^{+}$apoptotic cells compared with the $2 \mathrm{~B} 4{ }^{-} \mathrm{CD} 8^{+} \mathrm{T}$ cell subset (Figure $5 \mathrm{C}$ ). In sum, these data suggest that 2B4 expression on $\mathrm{CD} 8^{+} \mathrm{T}$ cells is also associated with increased cell apoptosis in human patients with sepsis.

\section{Discussion}

The data presented here show that memory $\mathrm{CD} 8^{+} \mathrm{T}$ cells are more susceptible than naive $\mathrm{CD} 8^{+} \mathrm{T}$ cells to sepsis-induced attrition, highlighting the important concept that memory $\mathrm{T}$ cells may behave differently than naive $\mathrm{T}$ cell populations during sepsis-induced immune dysregulation. Because the $\mathrm{T}$ cell compartments of 
A

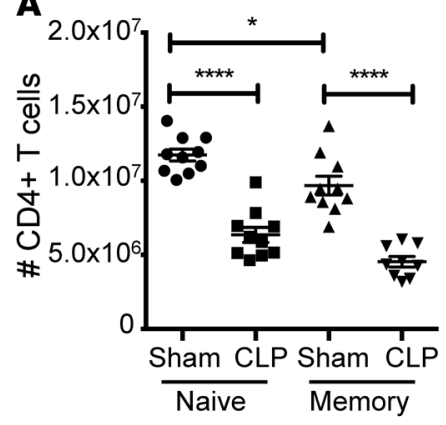

B

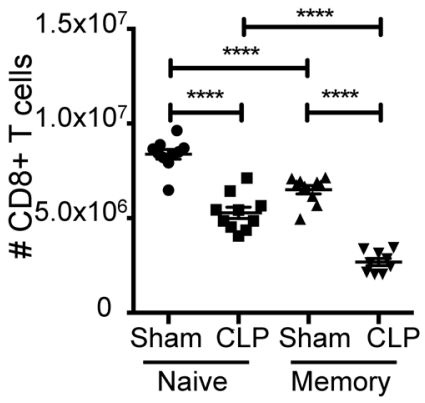

C

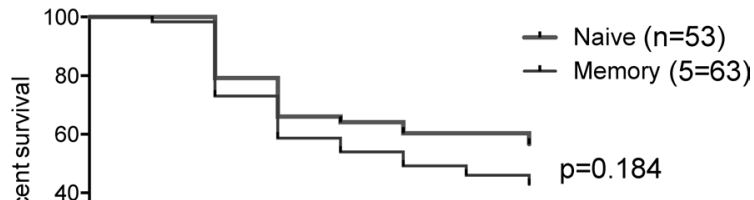

ब

\section{D}
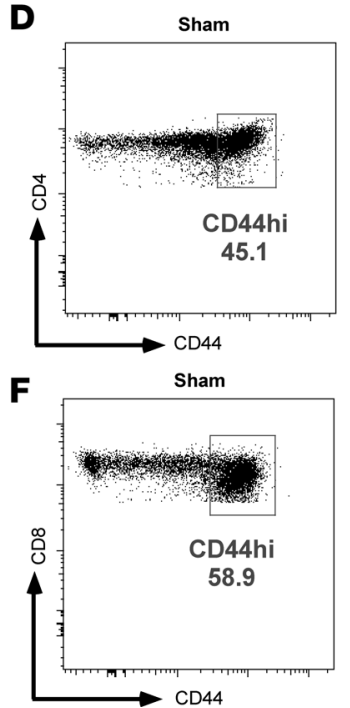

CLP

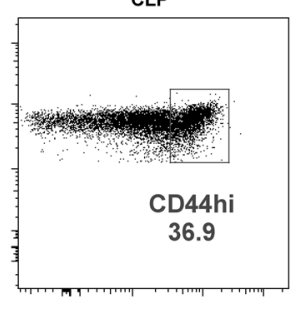

CLP

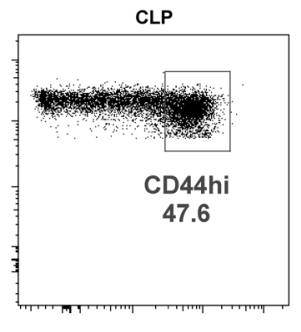

E
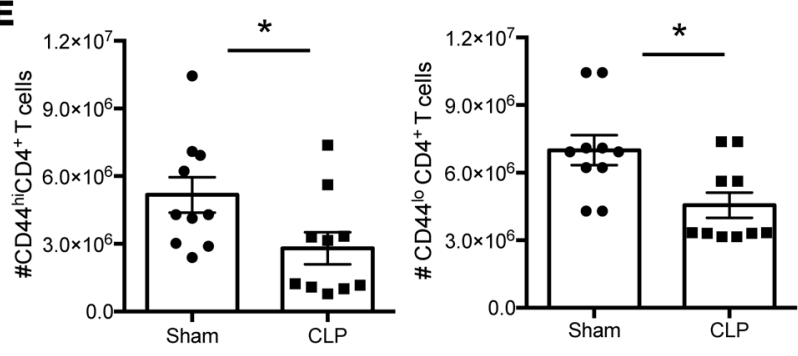

G

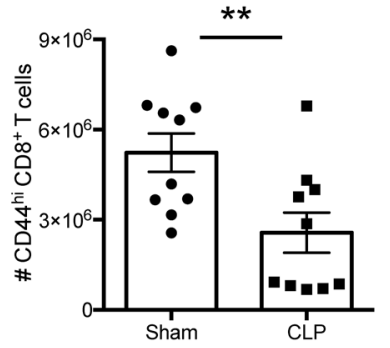

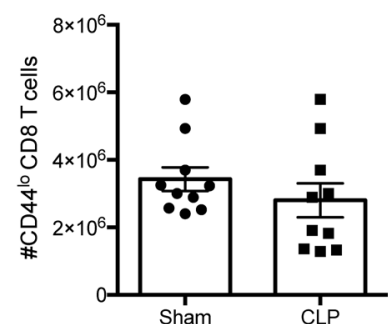

Figure 2. "Memory mice" exhibit significantly increased T cell loss during sepsis compared with naive hosts. (A and B) Summary quantification of total number of $\mathrm{CD}^{+}$and $\mathrm{CD} 8^{+} \mathrm{T}$ cells in the spleen following sham or CLP surgery in either naive mice or memory mice generated as described in Figure 1. Groups $(n=10)$ were compared using a nonparametric, 2-way ANOVA. (C) Kaplan-Meier survival analysis of mortality in animals that had sepsis induced via CLP in either the presence or absence of memory T cells. (D) Representative flow cytograms indicating CD44 expression on CD4+ ${ }^{+}$cells after sham or CLP surgery. (E) Summary of total CD44 ${ }^{\text {hi }} \mathrm{CD} 4^{+}$and $\mathrm{CD} 44^{\circ} \mathrm{C} C D 4^{+} \mathrm{T}$ cells, respectively, after sham or CLP surgery. (F) Representative flow cytograms indicating CD44 expression on CD8 ${ }^{+} T$ cells after sham or CLP surgery. (C) Summary of total CD44hicD4 ${ }^{+}$and CD44 ${ }^{\circ} C D 8^{+} T$ cells, respectively, after sham or CLP surgery. In E and $\mathbf{G}$, groups $(n=10)$ were compared with the Mann-Whitney nonparametric test. ${ }^{*} P<0.05,{ }^{* *} P<0.01$, and ${ }^{* * *} P<0.0001$.

adult humans contain greater than $50 \%$ memory $\mathrm{T}$ cells $(16,17)$ while laboratory mice possess relatively few memory $\mathrm{T}$ cells, these data support the concept that analyzing the behavior of antigen-experienced immune systems during sepsis might yield novel insights closely mirroring the pathophysiology of human sepsis. This is potentially critically important for the field of sepsis, where numerous targets and therapeutics that looked promising in initial preclinical rodent models have failed when tested in human patients with sepsis. Some have posited that this indicates that murine hosts are a poor model for studying human sepsis (43). Our study instead suggests that generating mouse models that more closely recapitulate the antigen-experienced human immune system might help bridge this divide.

Numerous studies have shown that sepsis induces a significant increase in T cell apoptosis (9-13), including both antigen-dependent and -independent memory $\mathrm{CD} 8^{+} \mathrm{T}$ cells $(15,44)$. In our study, we identified a significant loss of T cells during sepsis in memory mice. Both CD $44^{\mathrm{hi}} \mathrm{CD} 4^{+}$and CD $44^{\mathrm{lo}} \mathrm{CD} 4^{+}$ $\mathrm{T}$ cells were reduced after CLP. However, only $\mathrm{CD} 44^{\mathrm{hi}} \mathrm{CD} 8^{+}$but not $\mathrm{CD} 44^{\text {lo }} \mathrm{CD} 8^{+} \mathrm{T}$ cells were decreased following sepsis, which was in line with a previous study in naive mice (15). It is also interesting to note that we observed a modest but statistically significant reduction in the number of $\mathrm{T}$ cells between the naive versus memory sham-operated mice, particularly within the $\mathrm{CD} 8^{+} \mathrm{T}$ cell compartment (Figure 2A). Because we know that memory $\mathrm{T}$ cells are more susceptible to sepsis-induced apoptosis (Figure $2 \mathrm{G})$, we posit that the data shown in Figure 2A suggest that sterile inflammation induced by sham surgery could induce a weaker version of the same phenomenon (i.e., memory $\mathrm{T}$ cell apoptosis). 
A

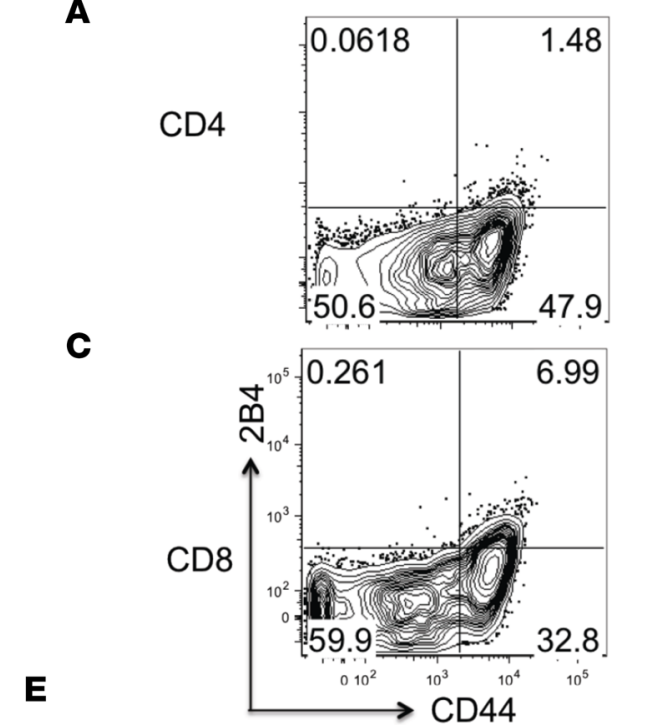

B

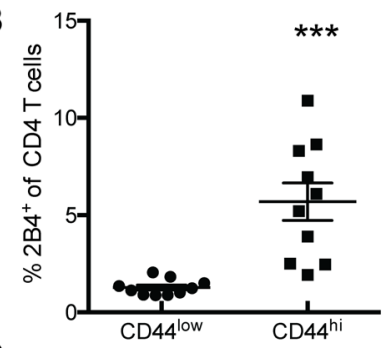

D

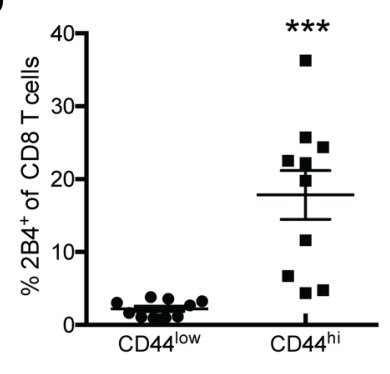

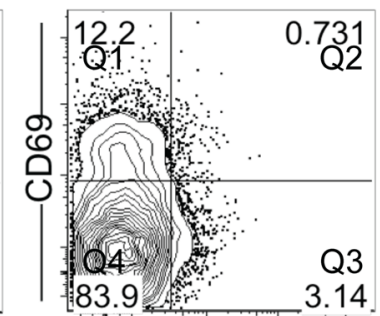

3.14

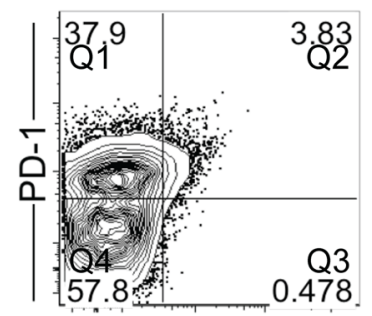

$\mathbf{F}$
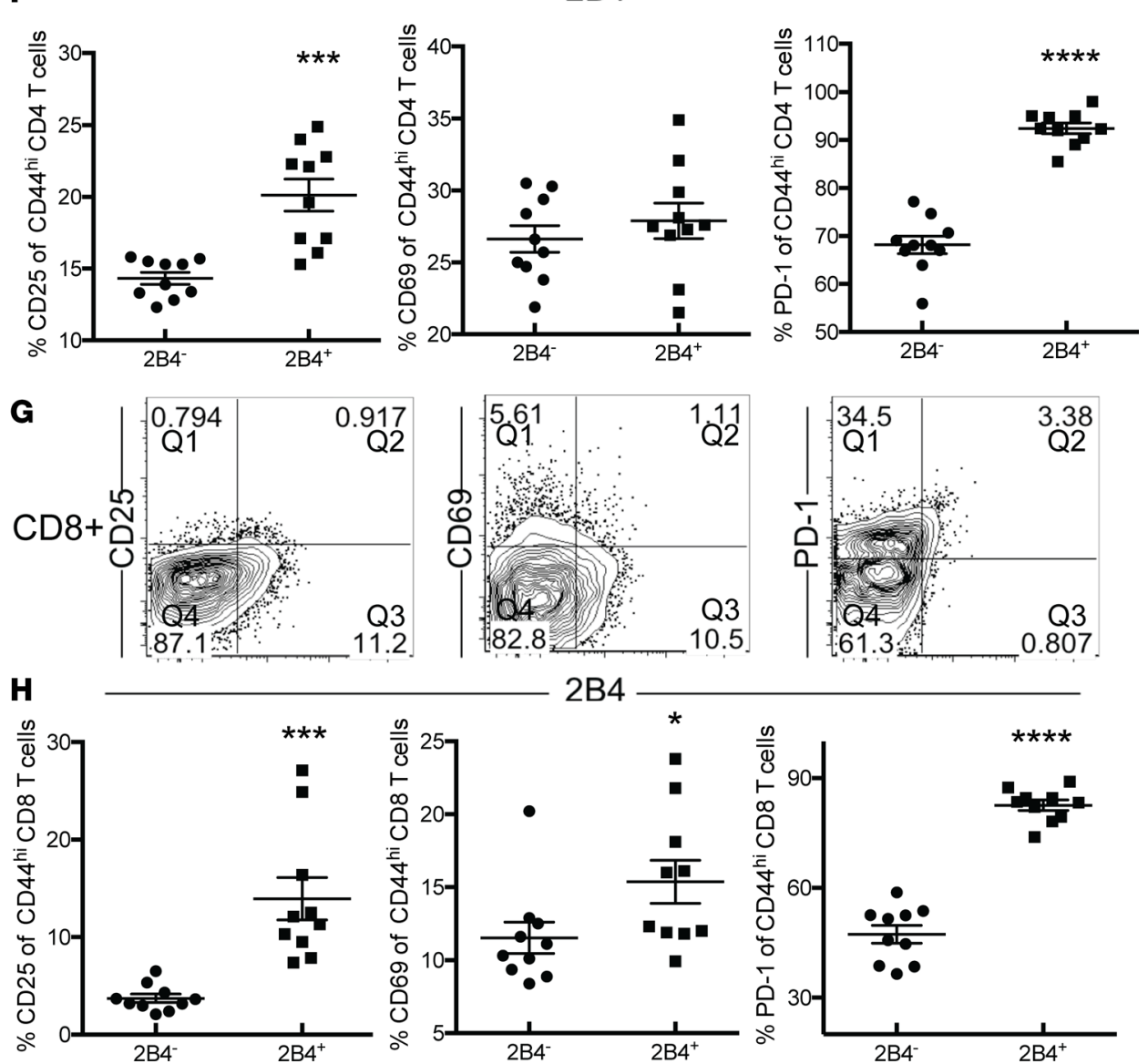

Figure 3. 2B4 coinhibitory receptor is preferentially upregulated on CD44 ${ }^{\text {hi }}$ memory $T$ cells during sepsis. Naive B6 mice were infected with Listeria. Mice were infected with LCMV 30 days later. CLP was performed 25 days after LCMV infection, and expression of $2 \mathrm{~B} 4$ on $\mathrm{CD} 44^{\text {10 }}$ and $\mathrm{CD} 44^{\text {hi }} \mathrm{CD} 4^{+}$ and $C D 8^{+} T$ cells in the spleen was assessed via flow cytometry. (A) Frequency of 2B4 expression on total $C D 4^{+} T$ cells. (B) Summary data depicting frequency of 2B4 expression on $\mathrm{CD} 44^{\circ} \mathrm{CD} 4^{+}$and CD44 ${ }^{\text {hi }}{ }^{C D} 4^{+} \mathrm{T}$ cells. (C) Frequency of 2B4 expression on total CD8 ${ }^{+} \mathrm{T}$ cells. (D) Summary data depicting frequency of 2B4 expression on CD44 ${ }^{10}$ and CD44 ${ }^{\text {hi }}$ CD8 ${ }^{+} T$ cells. (E) Representative plots depicting frequency of CD25, CD69, and PD-1 within $2 \mathrm{~B}^{+}{ }^{+} \mathrm{CD} 4{ }^{+}$and $2 \mathrm{~B} 4-\mathrm{CD} 4^{+} \mathrm{T}$ cell compartments. (F) Summary of data presented in E. Percentages of $\mathrm{CD}^{2} 5^{+}, \mathrm{CD} 69^{+}$, and $\mathrm{PD}-1^{+}$of 2B4- cells were calculated by dividing Q1 in the plot shown by Q4. Percentages of $\mathrm{CD}_{25}, \mathrm{CD}^{+} 9^{+}$, and $\mathrm{PD}-1^{+}$of $2 \mathrm{~B} 4^{+}$cells were calculated by dividing $\mathrm{Q} 2$ in the plot shown by Q3. (G) Representative plots depicting frequency of CD25, CD69, and $\mathrm{PD}-1$ within $2 \mathrm{~B} 4^{+} \mathrm{CD} 4^{+}$and 2B4-CD8 ${ }^{+} \mathrm{T}$ cell compartments. (H) Summary of data presented in $\mathbf{G}$. Percentages of $\mathrm{CD}_{25}+\mathrm{CD}^{\circ} 9^{+}$, and $\mathrm{PD}-1^{+}$of $2 \mathrm{~B} 4^{-}$cells were calculated by dividing $Q 1$ in the plot shown by Q4. Percentages of CD25+, CD69', and $\mathrm{PD}-1^{+}$of $2 \mathrm{~B} 4^{+}$cells were calculated by dividing Q2 in the plot shown by Q3. Groups $(n=10)$ were compared with the Mann-Whitney nonparametric test. ${ }^{*} P<0.05$, ${ }^{*}{ }^{*} P<0.001$, and ${ }^{* * *} P<0.0001$. 


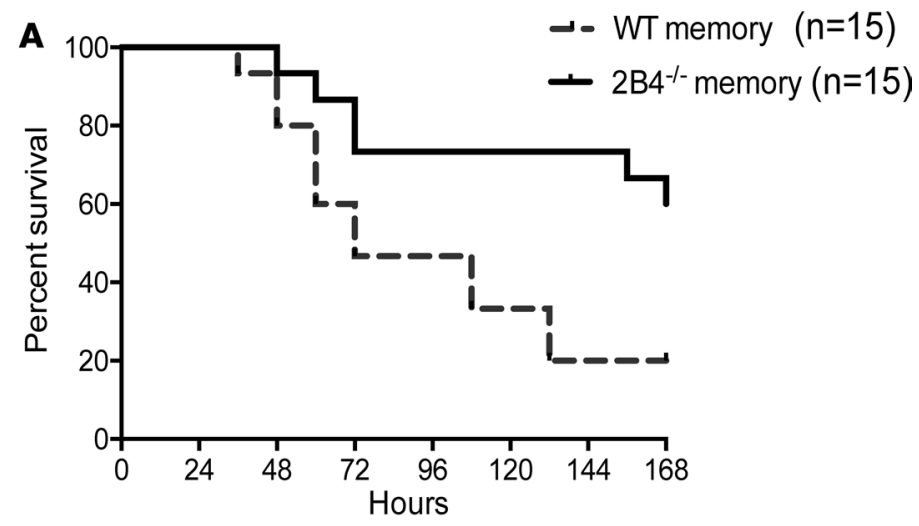

B
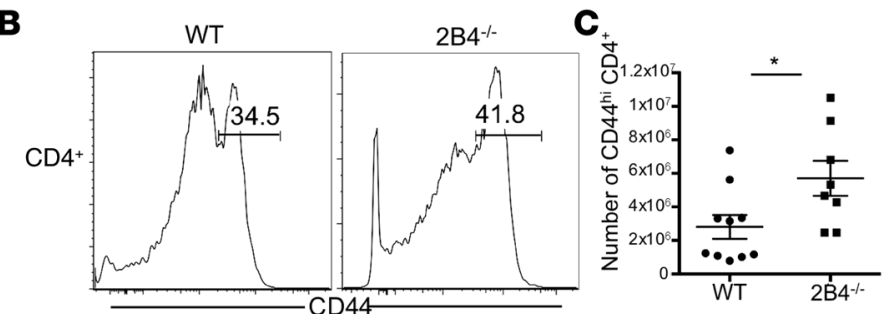

D

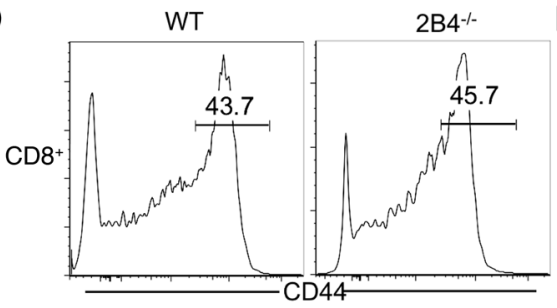

$\mathbf{E}_{+\infty}$

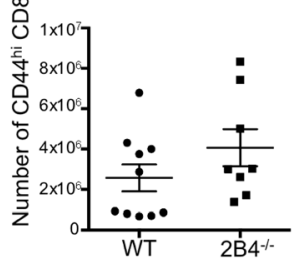

CD4
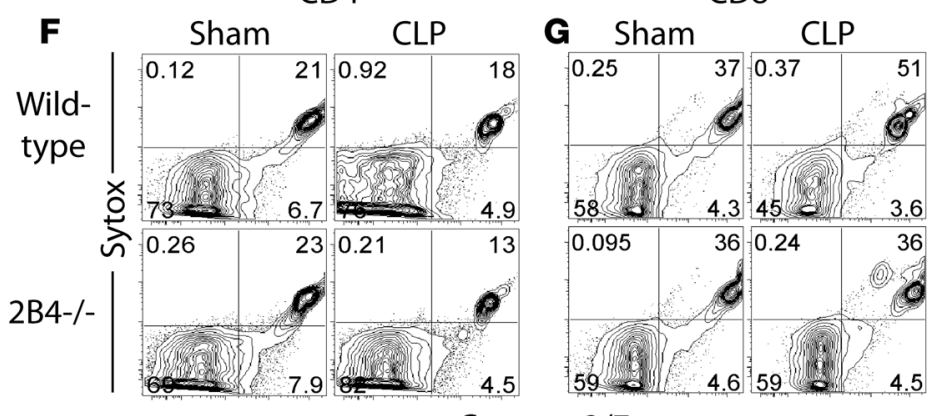

Caspase 3/7

\section{H}

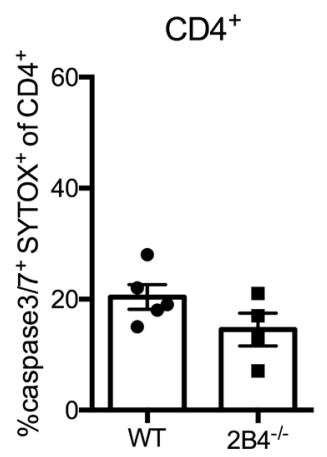

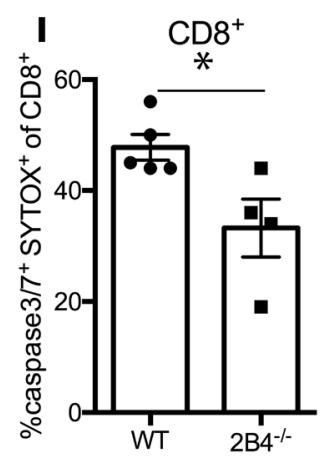

Figure 4. 2B4 deficiency rescues memory mice from sepsis mortality. (A) Kaplan-Meier survival curve comparing mortality of WT memory $(n=15)$ and 2B4 ${ }^{-1}$ memory mice $(n=15)$ after CLP. $P<0.0001$. (B-E) Analysis of absolute numbers of CD44 $4^{\text {hi }} \mathrm{CD} 4^{+}$(B and $\mathbf{C}$ ) and $\mathrm{CD} 44^{\text {hic }} \mathrm{CD} 8^{+}$( $\mathbf{D}$ and $\left.\mathbf{E}\right) \mathrm{T}$ cells obtained from the spleens of WT versus $2 \mathrm{~B}^{-1-}$ T cells at 24 hours after CLP. (F-I) Analysis of caspase $-3 / 7^{+}$and $\mathrm{SYTOX}{ }^{+}$cells among $\mathrm{CD}^{+}$and $\mathrm{CD} 8^{+} \mathrm{T}$ cell subsets obtained from the spleens of WT and $2 \mathrm{~B} 4^{-/-}$animals at 24 hours after CLP. Groups ( $n=4-5 /$ group, representative of 2 independent experiments with a total of $n=10$ /group) were compared with the Mann-Whitney nonparametric test. ${ }^{*} P<0.05$.

This interesting idea warrants further investigation. However, despite this significant impact of memory status on $\mathrm{CD}^{+} \mathrm{T}$ cell attrition during sepsis, we did not observe a significant increase in mortality in memory mice using this model. It is possible that this is due to a limited breadth of memory $\mathrm{T}$ cells before sepsis in this model because only 2 infections were used to generate the CD $44^{\text {hi }}$ memory $\mathrm{T}$ cell compartment. Although several studies have demonstrated that memory $\mathrm{T}$ cells are cross-reactive and can respond not only to the priming antigen but also to a spectrum of related antigens (45-47), this memory $\mathrm{T}$ cell compartment may be narrower in its specificity compared with that of humans. Thus, this limited repertoire of the memory $\mathrm{T}$ cells generated here is a potentially important limitation of the model. Alternatively, there may be a "threshold effect" with regard to the impact of $\mathrm{T}$ cell apoptosis on mortality during sepsis: Although we observed an increase in $\mathrm{T}$ cell apoptosis in the memory mice, it may not have been a large enough effect to influence overall mortality. Nevertheless, our results indicate that rescuing the loss of memory $\mathrm{T}$ cell number and functionality (in this case via deletion of 2B4) may be beneficial for increasing sepsis survival.

Indeed, in addition to our group, 3 other groups are currently studying the impact of antigen experience or infectious history on sepsis physiology. The Lederer and Badovinac/Griffiths labs have used pet store-derived "dirty mice" to generate T cell memory before sepsis induction (48, 49). Griffiths and Badovinac showed that B6 mice that had been cohoused with pet store mice exhibited significantly worsened survival following sepsis (49), and Deutschman's group showed that animals exposed to anti-CD3-mediated $\mathrm{T}$ cell activation and memory $\mathrm{T}$ cell generation demonstrated increased immune dysregulation following sepsis induction 30 days later (50). Each model has its own distinct advantages, in particular the fact that working with naturally colonized "dirty mice" may represent the most physiologically relevant way to generate T cell memory. Results from our model will synergize with data obtained from these related studies, in that in our system we can be certain that the observed effects are the result of immunologic memory and not the result of persistent, chronic infection in the "dirty mouse" models, as might occur following the transmission of murine cytomegalovirus, $\gamma$-herpesvirus 68 

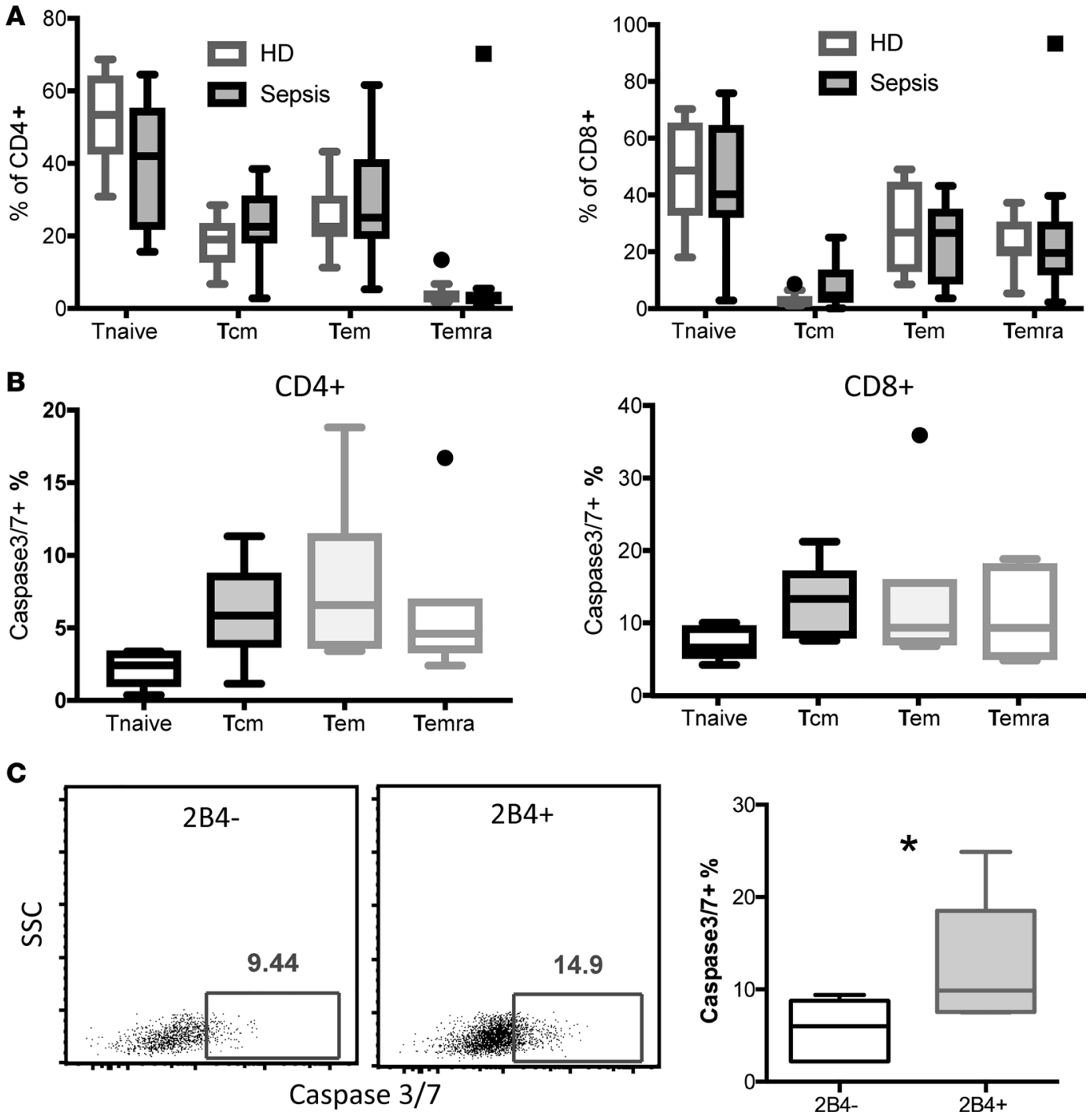

Figure 5. $2 \mathrm{B4}^{+} \mathrm{CDB}^{+} \mathrm{T}$ cells in patients with sepsis exhibited increased cell apoptosis. PBMCs were isolated from $n=$ 14 patients with sepsis under an IRB-approved protocol within 24 hours of a sepsis diagnosis and from $n=10$ normal healthy controls. (A) Frequencies of memory T cell subsets in $n=10 \mathrm{HDs}$ versus $n=7$ patients with sepsis. Naive T cells ( $T_{\text {naive }}$ ) were identified by gating on CD45RA+CCR7 $7^{+}$; central memory $T$ cells $\left(T_{c m}\right)$ were gated on CD45RA-CCR7 $7^{+} ; T_{\text {em }}$ were gated on CD45RA-CCR7-; and $\mathrm{T}_{\text {emra }}$ were gated on CD45RA+CCR7-. Cells from septic patients 1-7 as identified in Supplemental Table 1 were used in $\mathbf{A}$. The box plots depict the minimum and maximum values (whiskers), the upper and lower quartiles, and the median. The length of the box represents the interquartile range. (B) Active caspase 3/7 staining on $\mathrm{CD}^{+}$and $\mathrm{CD} 8^{+} T$ cell subsets isolated from $n=7$ patients with sepsis was determined by flow cytometry. Summary data of frequencies of active caspase-3/7+ $T$ cells within memory $T$ cell subsets of $C D 4^{+} T$ cells (left) and CD8 ${ }^{+} \mathrm{T}$ cells (right) are displayed. (C) CD8 ${ }^{+} \mathrm{T}$ cells were further divided into $2 \mathrm{~B} 4^{-}$and $2 \mathrm{~B} 4^{+}$populations and caspase-3/7 activity was assessed. Representative flow plots for caspase- $3 / 7$ staining in $C D 8^{+} 2 B 4^{-}$and $C D 8^{+} 2 B 4^{+} T$ cells. Summary data of frequencies of caspase-3/7+ cells within $2 \mathrm{~B} 4-\mathrm{CD} 8^{+}$and $2 \mathrm{~B} 4^{+} \mathrm{CD} 8^{+}$T cells. Cells from septic patients $8-14$ as identified in Supplemental Table 1 were used in $\mathbf{B}$ and $\mathbf{C} .{ }^{*} P<0.05$. SSC, side scatter.

(an Epstein-Barr virus homolog), or murine polyomavirus (a persistent viral infection endemic to almost all wild rodents and humans). Overall, these studies have together illuminated the fact that the actions of memory lymphocytes significantly influence immune dysregulation during sepsis and that a significant knowledge gap exists in understanding the molecular pathways that mediate this effect.

In a previous study, we reported that 2B4 signals play a crucial role in mediating $\mathrm{T}$ cell dysregulation and mortality during sepsis in naive animals (42). Here, using a memory model to better approximate the antigen-experienced immune systems of adult humans, we also found that $2 \mathrm{~B} 4^{-/-}$memory mice exhibited a significantly higher survival rate following sepsis compared with WT memory CLP controls. 
Although our study focused on the role of 2B4 on T cells, it is worth noting that 2B4 is also highly expressed on NK cells. Although we have previously determined that 2B4 deficiency on NK cells did not contribute to the overall survival benefit observed in 2B4-/- mice, "memory" NK cells have been shown to be generated following exposure to IL-12 or IL-18 (in the presence or absence of IL-15) (51). As such, future research should determine whether cytokine-driven memory NK cells are generated in this model and whether 2B4 deficiency plays a differential role on those memory NK cells relative to the negligible role we found it to play on "naive" NK cells during sepsis.

Our previous report on naive animals indicated that $2 \mathrm{~B} 4$ coinhibitory signaling on $\mathrm{CD} 4^{+} \mathrm{T}$ cells functioned in a cell-intrinsic manner to mediate immune dysfunction and mortality during sepsis (42). In the current study, we found that loss of $2 \mathrm{~B} 4$ reversed attrition of $\mathrm{CD} 4{ }^{+} \mathrm{CD} 44^{\mathrm{hi}} \mathrm{T}$ cell populations. $2 \mathrm{~B} 4$ deficiency was associated with a decrease in active caspase- $3 / 7^{+} \mathrm{SYTOX}{ }^{+} \mathrm{CD} 4^{+} \mathrm{T}$ cells. Moreover, studies of cells isolated from human patients with sepsis indicated that the frequency of caspase- $3 / 7^{+}$cells was higher in $2 \mathrm{~B} 4^{+} \mathrm{CD}^{+} \mathrm{T}$ cells during sepsis relative to $2 \mathrm{~B} 4^{-} \mathrm{CD} 8^{+} \mathrm{T}$ cells. Taken together, these complementary mouse and human data strongly suggest that expression of $2 \mathrm{~B} 4$ promotes memory $\mathrm{CD} 4^{+} \mathrm{T}$ cell apoptosis during sepsis and raise the possibility that blockade of this signal could limit this deleterious effect and promote immune competence. To understand why the loss of 2B4 coinhibitory signaling can prevent memory $\mathrm{T}$ cell attrition during sepsis, we assessed the phenotype of $2 \mathrm{~B} 4^{+}$versus $2 \mathrm{~B} 4^{-}$memory $\mathrm{T}$ cells during sepsis and found that the $2 \mathrm{~B} 4^{+} \mathrm{CD} 44^{\text {hi }}$ subset contained a higher frequency of activated $\mathrm{CD} 25^{+} \mathrm{CD} 69^{+}$cells within both the $\mathrm{CD}^{+}$and $\mathrm{CD} 8^{+}$compartments compared with the $2 \mathrm{~B} 4^{-} \mathrm{CD} 44^{\text {hi }}$ subsets during sepsis. In sum, our results indicate that targeting $2 \mathrm{~B} 4$ coinhibitory signaling may be a potential immunomodulatory therapy to improve outcomes in antigen-experienced human patients with sepsis.

\section{Methods}

Mice. We purchased 6-week-old male B6 mice from The Jackson Laboratory. 2B4-knockout mice on a B6 background, a gift of C. Terhorst (Beth Israel Deaconess Medical Center, Harvard Medical School, Boston, Massachusetts, USA), were bred and maintained in an approved animal facility at Emory University. We used age-matched $2 \mathrm{~B} 4^{-/-}$mice as $\mathrm{B} 6$ mice. All mice were maintained according to the Emory University Institutional Animal Care and Use Committee guidelines (protocol number 2003238-082518).

Generation of "memory mice." Both WT and 2B44-/ mice were infected with $1 \times 10^{4} \mathrm{CFU}$ of Listeria monocytogenes in $500 \mu \mathrm{PBS}$ intraperitoneally. On days 10 and 25 after infection, we assessed the frequency of $\mathrm{CD} 44^{\mathrm{hi}} \mathrm{CD}^{+}$and $\mathrm{CD} 44^{\mathrm{hi}} \mathrm{CD} 8^{+} \mathrm{T}$ cells. Mice were infected with $2 \times 10^{5}$ PFU LCMV intraperitoneally 30 days after infection, and the frequency of CD44 4 hemory $\mathrm{CD} 4^{+}$and $\mathrm{CD} 44^{\mathrm{hi}}$ memory $\mathrm{CD} 8^{+} \mathrm{T}$ cells were assessed on days 40 and 55 following the first infection. Both of these infections are acutely cleared, allowing us to assess the impact of $\mathrm{T}$ cell memory in the absence of active infection. Two months after Listeria infection, groups of mice underwent CLP or sham surgery as indicated.

Sepsis model. Animals were subjected to the CLP model of septic peritonitis on day 60 following the first infection. Mice were anesthetized via inhaled isoflurane, and a midline abdominal incision was made. The cecum was exteriorized, ligated, and punctured twice with a 25-gauge needle. The bowel was then returned to the abdominal cavity, and the incision was closed. All mice received buprenorphine $(0.1 \mathrm{mg} / \mathrm{kg})$ to relieve pain before the CLP procedure. Mice undergoing sham surgery received only the operation without ligation and puncture. Mice received a 1-ml subcutaneous injection of sterile saline immediately after surgery, as well as antibiotics (50 mg/ $\mathrm{kg}$ of ceftriaxone and $35 \mathrm{mg} / \mathrm{kg}$ metronidazole) designed to mimic the early bundle treatment of patients with sepsis. Antibiotics were injected subcutaneously at 12, 24, and 36 hours after surgery. Mice were euthanized using $\mathrm{CO}_{2}$ asphyxiation at designated time points.

Flow cytometry. Spleens were harvested after mice were sacrificed at 24 hours after CLP, and then spleens were processed to single-cell suspensions in a $70-\mu \mathrm{m}$ filter placed over a $50-\mathrm{ml}$ conical tube. Samples were rinsed with $10 \mathrm{ml}$ cold PBS, and $200 \mu \mathrm{l}$ from each spleen was aliquoted in a 96-well plate for staining. Alexa Fluor 700 anti-CD3 (BD Biosciences), anti-CD4-PB (BD Biosciences), anti-CD8-PO (Biolegend), and anti-CD44-PerCP (Biolegend) were used to stain to distinguish the naive and memory $\mathrm{CD} 4^{+}$and $\mathrm{CD}{ }^{+} \mathrm{T}$ cells. Anti-CD25-FITC (Biolegend), anti-CD69-PE (Biolegend), anti-CD62L-PE Cy7 (BD Biosciences), anti-2B4-APC, anti-PD-1-APCCy7, anti-LAG-3-FITC (all from eBioscience) were used for surface staining to determine the T cell phenotype. Anti-active caspase-3/7 and SYTOX were used per manufacturer's instructions to detect apoptotic cells. Accucheck Counting Beads (Thermo Fisher Scientific) were added during staining to calculate the absolute number of $\mathrm{T}$ cells per spleen. Human PBMCs were stained with anti-CCR7, anti-CD45RA, anti-CD4, anti-CD8, and 
anti-caspase-3/7 (Invitrogen). All the samples were run on an LSR II flow cytometer (BD Biosciences). FlowJo software (Tree Star Inc.) was used to analyze the data.

Human patients. Blood was collected from patients with sepsis within the first 24 hours of meeting the consensus clinical definition of sepsis. Average age of the cohort with sepsis analyzed here was $49.4 \pm$ 18.2 years and was not significantly different from the average age of the HDs. Similarly, the sex distributions within the sepsis versus HD cohorts were not different. In terms of severity of sepsis, the mean sequential organ failure assessment score was $7.6 \pm 2.3$, and the mean acute physiology, age, and chronic health evaluation score was $21.1 \pm 10.4$. The mean length of hospital stay for this cohort was $23.7 \pm 16.4$ days, and mean length of ICU stay was $9.1 \pm 7.5$ days. Additional demographic and clinical data are summarized in Supplemental Table 1. Values listed above represent the mean \pm SD.

Statistics. Statistical analyses were conducted using GraphPad Prism 6.0 software. Survival studies were analyzed using the log-rank test. Other variables were compared between the groups using 2-way ANOVA or the Mann-Whitney nonparametric test. All the data were expressed as mean \pm SEM. A $P$ value of less than 0.05 was considered statistically significant.

Study approval. Animal experiments were approved by the Emory University Institutional Animal Care and Use Committee, under protocol number 2003238-082518. Approval for procurement of HD and septic patient PBMCs was provided by the Emory University IRB, under protocol number 00002503. Informed consent was received from all human subjects.

\section{Author contributions}

MLF and CMC designed research studies; JX, CWC, YS, WZ, and SO conducted experiments and acquired data; JX, CWC, YS, SJL, CMC, and MLF analyzed data; MLF and JX wrote the manuscript; and all authors edited the manuscript.

\section{Acknowledgments}

This work was funded by R01s GM113228, GM104323, and GM109779 to MLF and CMC and AI104699 to MLF. The authors would like to thank Jennifer Robertson (Emory Transplant Center) and Leona Wells (Emory University Hospital) for technical assistances.

Address correspondence to: Mandy L. Ford, 101 Woodruff Circle, Suite WMB 5105, Atlanta, Georgia 30322, USA. Phone: 404.727.2900; Email: mandy.ford@emory.edu.

JX's present address is: Department of Critical Care Medicine, Zhongda Hospital, School of Medicine, Southeast University, Nanjing, China, 210009

1. Rhee C, et al. Incidence and trends of sepsis in US hospitals using clinical vs claims data, 2009-2014. JAMA. 2017;318(13):1241-1249.

2. Rhodes A, et al. Surviving sepsis campaign: international guidelines for management of sepsis and septic shock: 2016. Crit Care Med. 2017;45(3):486-552.

3. Seymour CW, et al. Time to treatment and mortality during mandated emergency care for sepsis. $N$ Engl J Med. 2017;376(23):2235-2244.

4. Angus DC, van der Poll T. Severe sepsis and septic shock. N Engl J Med. 2013;369(21):2063

5. Gaieski DF, Edwards JM, Kallan MJ, Carr BG. Benchmarking the incidence and mortality of severe sepsis in the United States. Crit Care Med. 2013;41(5):1167-1174.

6. Angus DC, Linde-Zwirble WT, Lidicker J, Clermont G, Carcillo J, Pinsky MR. Epidemiology of severe sepsis in the United States: analysis of incidence, outcome, and associated costs of care. Crit Care Med. 2001;29(7):1303-1310.

7. Martin GS, Mannino DM, Eaton S, Moss M. The epidemiology of sepsis in the United States from 1979 through 2000. NEngl JMed. 2003;348(16):1546-1554

8. Carrico CJ, Meakins JL, Marshall JC, Fry D, Maier RV. Multiple-organ-failure syndrome. Arch Surg. 1986;121(2):196-208

9. Hotchkiss RS, Monneret G, Payen D. Sepsis-induced immunosuppression: from cellular dysfunctions to immunotherapy. Nat Rev Immunol. 2013;13(12):862-874.

10. Hotchkiss RS, Monneret G, Payen D. Immunosuppression in sepsis: a novel understanding of the disorder and a new therapeutic approach. Lancet Infect Dis. 2013;13(3):260-268.

11. Hotchkiss RS, Karl IE. The pathophysiology and treatment of sepsis. N Engl J Med. 2003;348(2):138-150

12. Hotchkiss RS, et al. Sepsis-induced apoptosis causes progressive profound depletion of B and CD4 $4^{+} \mathrm{T}$ lymphocytes in humans. J Immunol. 2001;166(11):6952-6963.

13. Hotchkiss RS, et al. Role of apoptosis in Pseudomonas aeruginosa pneumonia. Science. 2001;294(5548):1783.

14. Boomer JS, et al. Immunosuppression in patients who die of sepsis and multiple organ failure. JAMA. 2011;306(23):2594-2605. 
15. Serbanescu MA, et al. Attrition of memory CD8 T cells during sepsis requires LFA-1. J Leukoc Biol. 2016;100(5):1167-1180

16. Cossarizza A, et al. CD45 isoforms expression on $\mathrm{CD}^{+}$and $\mathrm{CD} 8^{+} \mathrm{T}$ cells throughout life, from newborns to centenarians: implications for T cell memory. Mech Ageing Dev. 1996;86(3):173-195.

17. Saule P, Trauet J, Dutriez V, Lekeux V, Dessaint JP, Labalette M. Accumulation of memory T cells from childhood to old age: central and effector memory cells in CD4(+) versus effector memory and terminally differentiated memory cells in CD8(+) compartment. Mech Ageing Dev. 2006;127(3):274-281.

18. Beura LK, et al. Normalizing the environment recapitulates adult human immune traits in laboratory mice. Nature. 2016;532(7600):512-516.

19. Chen L, Flies DB. Molecular mechanisms of T cell co-stimulation and co-inhibition. Nat Rev Immunol. 2013;13(4):227-242.

20. Crompton PD, Pierce SK. PD-L2 elbows out PD-L1 to rescue T cell immunity to malaria. Immunity. 2016;45(2):231-233.

21. Day CL, et al. PD-1 expression on HIV-specific T cells is associated with T-cell exhaustion and disease progression. Nature. 2006;443(7109):350-354.

22. McKinney EF, Lee JC, Jayne DR, Lyons PA, Smith KG. T-cell exhaustion, co-stimulation and clinical outcome in autoimmunity and infection. Nature. 2015;523(7562):612-616.

23. Inoue S, Bo L, Bian J, Unsinger J, Chang K, Hotchkiss RS. Dose-dependent effect of anti-CTLA-4 on survival in sepsis. Shock. 2011;36(1):38-44.

24. Shubin NJ, Chung CS, Heffernan DS, Irwin LR, Monaghan SF, Ayala A. BTLA expression contributes to septic morbidity and mortality by inducing innate inflammatory cell dysfunction. J Leukoc Biol. 2012;92(3):593-603.

25. Chang KC, et al. Blockade of the negative co-stimulatory molecules PD-1 and CTLA-4 improves survival in primary and secondary fungal sepsis. Crit Care. 2013;17(3):R85.

26. Brahmamdam P, Inoue S, Unsinger J, Chang KC, McDunn JE, Hotchkiss RS. Delayed administration of anti-PD-1 antibody reverses immune dysfunction and improves survival during sepsis. J Leukoc Biol. 2010;88(2):233-240.

27. Shubin NJ, Monaghan SF, Heffernan DS, Chung CS, Ayala A. B and T lymphocyte attenuator expression on CD4+ T-cells associates with sepsis and subsequent infections in ICU patients. Crit Care. 2013;17(6):R276.

28. Shao R, Li CS, Fang Y, Zhao L, Hang C. Low B and T lymphocyte attenuator expression on CD4 $4^{+}$T cells in the early stage of sepsis is associated with the severity and mortality of septic patients: a prospective cohort study. Crit Care. 2015;19:308.

29. Chang K, et al. Targeting the programmed cell death 1: programmed cell death ligand 1 pathway reverses $\mathrm{T}$ cell exhaustion in patients with sepsis. Crit Care. 2014;18(1):R3.

30. Chang KC, et al. Blockade of the negative co-stimulatory molecules PD-1 and CTLA-4 improves survival in primary and secondary fungal sepsis. Crit Care. 2013;17(3):R85.

31. Guignant C, et al. Programmed death-1 levels correlate with increased mortality, nosocomial infection and immune dysfunctions in septic shock patients. Crit Care. 2011;15(2):R99.

32. Huang $X$, et al. PD-1 expression by macrophages plays a pathologic role in altering microbial clearance and the innate inflammatory response to sepsis. Proc Natl Acad Sci U S A. 2009;106(15):6303-6308.

33. Monaghan SF, et al. Mechanisms of indirect acute lung injury: a novel role for the coinhibitory receptor, programmed death-1. Ann Surg. 2012;255(1):158-164.

34. Monaghan SF, et al. Programmed death 1 expression as a marker for immune and physiological dysfunction in the critically ill surgical patient. Shock. 2012;38(2):117-122.

35. Young JS, et al. Effect of PD-1: PD-L1 in invariant natural killer T-cell emigration and chemotaxis following sepsis. Shock. 2016;45(5):534-539.

36. Wang F, Huang X, Chung CS, Chen Y, Hutchins NA, Ayala A. Contribution of programmed cell death receptor (PD)-1 to Kupffer cell dysfunction in murine polymicrobial sepsis. Am J Physiol Gastrointest Liver Physiol. 2016;311(2):G237-G245.

37. Patera AC, Drewry AM, Chang K, Beiter ER, Osborne D, Hotchkiss RS. Frontline Science: defects in immune function in patients with sepsis are associated with PD-1 or PD-L1 expression and can be restored by antibodies targeting PD-1 or PD-L1. J Leukoc Biol. 2016;100(6):1239-1254.

38. Monneret G, Gossez M, Venet F. Sepsis in PD-1 light. Crit Care. 2016;20(1):186.

39. Gao DN, Yang ZX, Qi QH. Roles of PD-1, Tim-3 and CTLA-4 in immunoregulation in regulatory T cells among patients with sepsis. Int J Clin Exp Med. 2015;8(10):18998-19005.

40. Tang L, et al. Active players in resolution of shock/sepsis induced indirect lung injury: immunomodulatory effects of Tregs and PD-1. J Leukoc Biol. 2014;96(5):809-820.

41. Goyert SM, Silver J. Editorial: PD-1, a new target for sepsis treatment: better late than never. J Leukoc Biol. 2010;88(2):225-226.

42. Chen CW, et al. Cutting edge: 2B4-mediated coinhibition of $\mathrm{CD}^{+} \mathrm{T}$ cells underlies mortality in experimental sepsis. J Immunol. 2017;199(6):1961-1966.

43. Stortz JA, Raymond SL, Mira JC, Moldawer LL, Mohr AM, Efron PA. Murine models of sepsis and trauma: Can we bridge the gap? ILAR J. 2017;58(1):90-105. doi:10.1093/ilar/ilx007.

44. Duong S, Condotta SA, Rai D, Martin MD, Griffith TS, Badovinac VP. Polymicrobial sepsis alters antigen-dependent and -independent memory CD8 T cell functions. J Immunol. 2014;192(8):3618-3625.

45. Adams AB, et al. Heterologous immunity provides a potent barrier to transplantation tolerance. J Clin Invest. 2003;111(12):1887-1895.

46. Selin LK, et al. Memory of mice and men: CD8 ${ }^{+}$T-cell cross-reactivity and heterologous immunity. Immunol Rev. 2006;211:164-181.

47. Adams AB, Pearson TC, Larsen CP. Heterologous immunity: an overlooked barrier to tolerance. Immunol Rev. 2003;196:147-160

48. Guo F, et al. Comparing the phenotype betwen naturally-colonized "dirty mice" and laboratory "clean" mice by a CYTOFbased systems immunology approach. Shock. 2018;49(suppl 1):128.

49. Griffiths TS, et al. Physiology microbial exposure substantially influences de novo inflammatory responses in vivo. Shock. 2018;49(suppl 1):122.

50. Taylor MD, Abraham MN, Deutschamn CS. Induction of nonspecific memory T cells alters the immune response to cecal ligation and puncture (CLP). Shock. 2018;49(suppl 1):132.

51. Geary CD, Sun JC. Memory responses of natural killer cells. Semin Immunol. 2017;31:11-19. 